\title{
Correction to: An Observational View of Relationships Between Moisture Aggregation, Cloud, and Radiative Heating Profiles
}

\author{
Matthew D. Lebsock ${ }^{1}$ (D) Tristan S. L'Ecuyer ${ }^{2}$ - Robert Pincus ${ }^{3,4}$
}

Published online: 13 November 2017

(C) The Author(s) 2017

\section{Correction to: Surv Geophys \\ https://doi.org/10.1007/s10712-017-9443-1}

The article "An observational view of relationships between moisture aggregation, cloud and radiative heating profiles", written by Matthew D. Lebsock, Tristan S. L'Ecuyer and Robert Pincus, was originally published electronically on the publisher's internet portal (currently SpringerLink) on 31 October 2017 without open access.

With the author(s)' decision to opt for Open Choice, the copyright of the article was changed on [13 November 2017] to (C) The Author(s) 2017, and the article is forthwith distributed under the terms of the Creative Commons Attribution 4.0 International License (http://creativecommons.org/licenses/by/4.0/), which permits use, duplication, adaptation, distribution and reproduction in any medium or format, as long as you give appropriate credit to the original author(s) and the source, provide a link to the Creative Commons license and indicate if changes were made. The original article was corrected.

The original article can be found online at https://doi.org/10.1007/s10712-017-9443-1.

Matthew D. Lebsock

matthew.d.lebsock@jpl.nasa.gov

1 Jet Propulsion Laboratory, California Institute of Technology, Pasadena, CA 91109, USA

2 University of Wisconsin, Madison, WI 53706, USA

3 Cooperative Institute for Research in Environmental Sciences, University of Colorado, Boulder, CO 80309, USA

4 Physical Sciences Division, NOAA Earth System Research Lab, Boulder, CO 80305, USA 